\title{
Palestinian Refugees of Egypt: What Exit Options Are Left for Them?
}

\author{
Oroub El-Abed
}

\begin{abstract}
This paper, based on personal interviews, analysis of Egyptian administrative regulations, and observation of practice of international and regional agreements on refugees, considers the effects of displacement on the Palestinians' legal status and hence on the way they have conducted their livelihoods in Egypt. While Arab countries have offered to provide temporary protection to Palestinian refugees, as a result of political developments, including relations between the PLO and the host states, the rights afforded to Palestinians in Arab host states have varied greatly over time.

Palestinians in Egypt, since 1978, do not receive assistance from the government of Egypt and do not have access to any of its public services. Palestinians also do not receive any assistance or protection from UN bodies in charge of refugee issues. Both regional and international pledges and agreements have not been respected. The ambiguous legal status of Palestinians has affected their livelihoods in many ways. It has rendered their residence insecure and in many cases illegal. This has affected employment and education opportunities, as well as freedom of movement and association. The deprivation of rights and the unstable legal and economic conditions of Palestinians in Egypt has placed them in a state of "limbo."
\end{abstract}

\section{Résumé}

Cet article est fondé sur des interviews personnelles, sur une analyse des règlements administratives égyptiennes et sur une observation de la manière dont le droit international et les accords régionaux sur les réfugiés sont mis en pratique, et examine l'effet qu'a eu le déplacement sur le statut légal des Palestiniens et, par conséquent, sur la façon dont ils ont pu mener et gagner leur vie en Égypte. S'il est vrai que les pays arabes ont offert de fournir une protection temporaire aux réfugiés palestiniens, à cause des développements politiques, y compris les relations de l'OLP avec les pays d'accueil, les droits concédés aux $\mathrm{Pa}$ lestiniens dans les pays hôtes arabes ont varié grandement au cours des années.

Depuis 1978, les Palestiniens qui se trouvent en Égypte ne reçoivent plus d'assistance du gouvernement égyptien et n'ont pas accès aux services publics. En plus, les Palestiniens ne reçoivent aucune assistance ou de protection des organismes onusiens en charge des questions des réfugiés. Les promesses et les accords, tant régionaux qu'internationaux, n'ont pas été respectés. L'ambiguïté du statut légal des Palestiniens a affecté leur capacité de gagner leur vie de diverses façons. Elle a rendue leur résidence précaire, souvent même illégale. Cela a affecté leur possibilité de trouver de l'emploi et d'avoir accès à l'éducation, ainsi que leur capacité de se déplacer et de s'organiser librement en groupe associatifs. Privés de droits et légalement et économiquement en situation précaire, les Palestiniens d'Égypte se retrouvent dans un état indéterminé.

B ased on reports of massacres, evidence of villages and towns being cleared of their populations, and a wellfounded fear of further persecution from Zionist guerrilla troops and later the Israeli Defence Forces, Palestinians fled their homes in Palestine in 1948 and in 1967 to seek shelter in neighbouring countries.

Much has been written on the causes of their flight and on their living conditions in what are known as "host countries." ${ }^{1}$ Little, however, has been written about those who fled to Egypt, numbering 13,000 in 1948 and 33,000 in $1969 .^{2}$ This paper is based on research which was conducted over two years (2001-2003) under the auspices of the Forced Migration and Refugee Studies Programme (FMRS) of the American University in Cairo (AUC). This paper, 
based on personal interviews with eighty Palestinian families (401 persons), considers the effects of displacement on their legal status and hence on the way they conducted their livelihoods in Egypt. Several factors affected their adjustment to the new environment - the personal resources they had to "reconstruct" in their lives and the attitude of the host country itself to them and their legal status.

This research approached the "field" from a descriptive perspective based on a qualitative case-study approach. Statistical sampling and quantitative data collection would not have been possible given the fact that the exact number of Palestinian refugees in Egypt is not known and the results of the census conducted by the government in 1995 are not available. A snowball method was used in reaching Palestinians dispersed all over the governorates of Egypt. When arriving in the area, the research team would ask a shopkeeper for a Palestinian resident. After finding the first Palestinian household, it would then make referrals to other households. The research team used an open-ended questionnaire which permitted Palestinians to elaborate on their answers and to clarify their coping strategies in Egypt.

Research into Palestinians in Egypt has the aim of providing an understanding of the difficulties they face and laying the foundation for possible projects or actions to benefit this community since it is neither protected nor assisted by any United Nations body. Until Palestinians can return to Palestine, these endeavours are intended to ensure them a decent life while they remain outside Palestine. Assistance efforts being considered include income-generation and educational skills training projects. Calling for an amelioration of Palestinians' living conditions in Egypt does not mean denying their right of return. On the contrary, the objective is to ensure their socio-economic rights and an acceptable legal status, wherever they are residing, meanwhile supporting their legal and political right to return to their homeland.

\section{Why Did Palestinians Go to Egypt?}

Palestinians went to Egypt either fearing persecution in Palestine or for socio-economic reasons and were denied access to Palestine as a result of occupation. The first category includes 1948 arrivals who are "Palestinian refugees" as well as those who fled to Egypt as a result of the Israeli occupation of the West Bank and Gaza in 1967, the so called "displaced Palestinians." The second category consists of those who were outside Palestine during the 1956 and 1967 wars and would not return to their homes and properties. This category includes those who sought employment and educational opportunities in Egypt between 1954 and 1967 but as a result of the 1967 occupation of the West Bank and
Gaza Strip, many of them could not return to Palestine and have had to remain in Egypt.

\section{Refugees and Displaced Persons}

The United Nations Relief and Works Agency (UNRWA) defines a "Palestine refugee" as "any person whose normal place of residence was Palestine during the period June 1, 1946 to May 15, 1948 and who lost both home and means of livelihood as a result of the 1948 conflict." This definition was made solely to enable UNRWA to determine eligibility for the agency's assistance programs in its five field operations: the Gaza Strip, the West Bank, Syria, Lebanon, and Jordan. ${ }^{3}$

Of Palestinians who sought refuge in Egypt, some lived temporarily in Gaza and registered with UNRWA, while others went directly from their homes in Palestine to Egypt so could not register with UNRWA. The majority of Palestinians in Egypt are from the latter group. Egypt's Department of Nationality and Passports had its own definition of them for the purposes of accommodating them in temporary refugee camps and providing relief through the Egyptian Higher Committee for Palestinian Immigrants. "Palestinian immigrants" were defined as those persons who sought refuge in Egypt from 1948 to $1950 .^{4}$

During the 1967 War, more Palestinians, most of them registered with UNRWA, fled from Gaza to Jordan and then Egypt. This displacement included two groups: "refugeesdisplaced" and "displaced" coming from Gaza. ${ }^{5}$ The "refugees-displaced" had been forced to flee Palestine for the second time, the first time being when they left their homes in Palestine for Gaza and the second time being when they left the territories occupied in 1967, which included Gaza. The "displaced" are original inhabitants of Gaza who were displaced for the first time by the 1967 War. Despite the fact that some were registered with UNRWA, those who arrived in Egypt did not receive assistance from any United Nations (UN) agency. ${ }^{6}$ The Egyptian Administrative Office of the Governor of Gaza, initially based in Gaza and later moved to Cairo, was the only administrative body dealing with Palestinians in Egypt. The office is still in existence.

\section{Socio-Economic Displacement}

After the Rhodes Armistice was signed in February of 1949 on the Greek island of Rhodes, Egypt assumed military and administrative control of Gaza. ${ }^{7}$ In 1954, when Gamal Abdel-Nasser became president, work in trade, industry, and transport between Gaza and Egypt was permitted. ${ }^{8}$ At the outbreak of the 1967 War, Palestinians who had been involved in these activities settled in Egypt because of the social and professional networks they had established there. 
In 1962, economic conditions in Gaza were deteriorating and unemployment increased. In response, Nasser called for Palestinians from Gaza with high school diplomas or college degrees to apply to work in public institutions in Egypt and regulations were issued to facilitate their employment. Those who responded were unable to return to Gaza when the 1967 War erupted and Israelis occupied Gaza. In addition, many Palestinians, as interviews revealed, sought education in prominent Egyptian universities. Again, due to the 1967 War, they were unable to return to Gaza. Other Palestinians went to Egypt as part of Red Cross efforts to reunite families that had been living in Gaza and whose relatives lived in Egypt.

\section{Socio-Economic Conditions Changed}

The policies implemented by Nasser beginning in 1954 welcomed Palestinians and treated them as if they were Egyptian nationals. Palestinians were able to enhance their livelihoods during this era and to access state services. Work was permitted and education, including university level was free. Most important, the administrative laws were amended so that the word "foreign" no longer applied to Palestinians.

Political events in the late 1970s marked the end of the golden era for Palestinians in Egypt. The Camp David peace accords and the killing of the Egyptian Minister of Culture Youssef al-Sibai in 1978 by a Palestinian faction group of Abu Nidal al-Banna had a negative impact on Egyptian policy toward Palestinians in Egypt. Laws and regulations were amended to treat Palestinians as foreigners. Their rights to free education, employment, and even residency were taken away from them. University education now has to be paid for in foreign currency. For example, according to a study conducted by Yassin from 1965 to 1978, Palestinian students studying at universities had numbered 20,000, but by 1985 the number had dropped to 4,500 . Those enrolled in public universities between the years 1997-1998 and 2000-2001 were 3,048. ${ }^{9}$

Those who had established themselves earlier in the public and the private sector were able to remain in their positions. Government employees or professionals, such as doctors and lawyers, kept their posts. No new Palestinians were hired by the state, however. With access to government jobs gone, they are left with the private sector and the informal economy. The private sector requires skills, which, without education, Palestinians are unable to obtain. It also requires work permits, considering that, in Egypt, the number of foreigners may not exceed 10 per cent of the workforce in each workplace. Palestinians are forced to find work in such sectors as driving trucks and taxis for others, bicycle repair shops, petty trade in commodities such as used clothing on the street, and suitcase merchants who take items from various parts of Egypt to sell in Gaza but now even this trade has stopped because of the second Intifada.

The situation is better for the employees of the Palestine Liberation Organization (PLO), the Palestine Liberation Army, and current and former Egyptian government employees. They are ensured regular income, and, later, a regular pension. In addition to the education of their children, they are exempted from 90 per cent of university fees.

While socio-economic conditions brought some Palestinians to Egypt, war prevented them from returning home. In September 2002, the United Nations High Commissioner for Refugees (UNHCR) reinterpreted Article 1D of the 1951 Convention relating to the Status of Refugees. ${ }^{10}$ UNHCR had previously viewed the article as excluding Palestinian refugees because they receive assistance from UNRWA; it now emphasized the second paragraph, which clarifies that Palestinian refugees are ipso facto refugees and are to be protected by UNHCR if assistance or protection of another UN body ceases. ${ }^{11}$ By this action, it has included Palestinians, particularly those not living within UNRWA fields of operation, within its protection mandate. The fact that these Palestinians are in dire need of protection is reflected in the numbers of young Palestinian men who are detained in Egyptian prisons indefinitely because they lack residence permits. Their choices are limited - find a country that will take them in or find a way of being deported to Gaza. But given the current Intifada and as Israel has the final decision on permitting entry, getting to Gaza has been impossible. Despite the recent reinterpretation of the Refugee Convention, Palestinians in Egypt still lack formal UNHCR protection and they are not assisted by UNRWA. The paper highlights the urgent need for international intervention to better protect the legal rights of Palestinians. Until there is a Palestinian state and Palestinians are able to go there, the Egyptian government should reconsider its policies on Palestinians and try to provide basic services for them.

\section{Legal Rights of Palestinians in Egypt}

Arab host states responded to the plight of displaced Palestinians by offering them temporary protection until they could return to Palestine. However, as a result of political developments, including relations between the PLO and the host states, the rights afforded to Palestinians in Arab host states have varied greatly over time. While the previous sections discussed the effects of changing administrative policies on the daily livelihood of Palestinians in Egypt, this part examines the legal status granted to Palestinians in Egypt.

As a result of their legal difficulties in Egypt, many Palestinians sought a way out. The establishment of the Pales- 
tinian Authority in Gaza and the West Bank revived hopes of returning to Palestine. For many, return to the homeland meant the materialization of a dream of reconstructing broken family ties and ties to the land, but most importantly, it meant securing legal status in a place where they belong. However, due to the Intifada and the continued occupation of the Palestinian territories and as a result of the international conventions and Arab league protocols that were not respected by Egypt, Palestinians' legal status is today "in limbo."

\section{Legal Status}

For the purpose of granting assistance in Egypt, the Egyptian Higher Committee for Palestinian Immigrants defined Palestinian refugees as persons who sought refuge in the country from 1948 to 1950 . To prove this, a person was required to have an identity card for temporary residence in Egypt issued by the Egyptian Department of Passports and Nationality. A ministerial decision was promulgated to allow issuing of the temporary residence identity documents (IDs) for Palestinian refugees. The decision stipulated that the IDs should not be renewed for more than one year and should indicate the material assistance that its holders were receiving. Meanwhile, the Government of All Palestine (GAP), ${ }^{12}$ a civil administrative government, moved its offices to Egypt in late 1948 and began issuing Palestinians with travel documents and birth certificates. Holders of GAP passports were granted one-year residence permits in Egypt but were not permitted to work. Written directly on the document were the words "work for or without wages is forbidden,"13 GAP papers and passports were largely symbolic, as was GAP itself.

In 1960, during the brief period of unity between Egypt and Syria, Decision No. 28 was issued stipulating the provision of travel documents for Palestinians. In order to receive such a document, a Palestinian had to prove refugee status by producing the ID issued earlier by the Egyptian Department of Passports and Nationality and also had to prove legal residence in Egypt. Article 2 prohibited the holder of the travel document from travelling between the northern (Syrian) and the southern (Egyptian) regions without having a visa as well as a return visa. Meanwhile, Egypt reassured Palestinians residing in its territories that they would not lose their Palestinian nationality. Interior Minister Zakaryia Muhi El-Din sent instructions to the Department of Immigration and Passports and Nationality emphasizing the need for the preservation of Palestinian nationality for Palestinians residents of the United Arab Republic (UAR) because they will return to their original homeland after its liberation. ${ }^{14}$
In 1964, Decision 181 was issued. Article 1 said that Palestinian refugees should be given temporary travel documents upon request but required applicants to provide proof of refugee status and have a valid Egyptian residence permit. Article 4 stated that the travel document would be valid for two years and could be extended for another two years, followed by one additional year for a maximum validity of five years. Article 5 stipulated that the travel document did not permit its holders to enter or transit through Egypt without a visa, transit visa, or return visa.

On September 11, 1965, Egyptian Foreign Minister Mahmoud Riyad ratified the protocol on the treatment of Palestinians in Arab states. While confirming the preservation of Palestinian nationality, the Arab states agreed to grant Palestinians living in host countries the right to work and be employed as nationals and the right to leave and return to the host country freely, and agreed to grant them valid travel documents upon request. ${ }^{15}$

\section{Arab Government Policies}

The League of Arab States resolutions on Palestinian refugees indicate the member states' commitment to finding a solution to the Palestinian plight by "ensuring their return to their homes and confirming preservation of their properties, their money, their life and their freedom," as stated in Resolution 205-17-3-1949. Concerning the treatment of Palestinian refugees, Resolution 391-10-1951 states,

The Council of the League approves the decision of the political committee with reference to the decision of the Palestinian permanent council to discuss all refugees' affairs thoroughly and to consider their need to work, to travel and to remain in the host countries. The council requires the committee to prepare a financial report on the needs for Palestinian refugees.

In 1952, the Arab League established the Administrative Office of Palestine. It has two sections: political and legal matters and refugee affairs. In addition, the political committee of the Council of the Arab League dealt with Palestinian refugee matters by approving a number of resolutions. Resolution 424-4-9-1952 stipulated that unified travel documents were to be issued to dispersed Palestinian families. This was later ratified when the Council decided to approve the issuing of unified travel documents to Palestinian refugees in Resolution 714-27-1-1954. Article 1 of this resolution stated,

The governments of state members at the League have agreed that each government should issue the Palestinian refugees residing in its territory, or falling under its care, temporary 
travel documents upon their request and in accordance with the provisions of the following articles unless they have obtained citizenship from one of the states."

In Resolution 462-23-9-1952, Article 1, the political committee advised Arab governments to postpone efforts to settle Palestinian refugees and called on the United $\mathrm{Na}$ tions to implement resolutions concerning the return of Palestinian refugees to Palestine and to compensate them for damage and property losses. In Article 2, it recommended that Arab countries hosting refugees create projects employing Palestinians and help them better their living conditions. While requesting Arab countries to coordinate with UNRWA in employment projects for Palestinians, the political committee confirmed that these projects would not permanently settle Palestinians and would preserve their right of return and right to compensation. In Article 3, the committee required Arab governments to co-ordinate efforts facilitating the travel of Palestinians and to co-operate for their temporary stay in host countries. The Arab League efforts culminated in 1965 with the adoption of the Casablanca Protocol on the Treatment of Palestinians.

The Arab League's Casablanca Protocol called on Arab governments to grant Palestinians residence permits, the right to work, and the right to travel on a par with citizens while at the same time emphasizing the importance of preserving Palestinian identity and maintaining the refugee status of Palestinians residing in host countries. At least on paper, the members of the Arab League expressed their solidarity with and sympathy for Palestinians and their rights. However, in practice, the Casablanca Protocol was ignored.

Realizing that the rights referred to in the protocol were not always being upheld in Arab host states and in view of the various problems facing Palestinian refugees, in December 1982 the Arab League called a meeting of the Council of Arab Ministers of the Interior, which adopted a "special resolution on the treatment of Palestinians in the Arab countries." Its operative paragraphs contain a number of important clarifications on the status of Palestinians in Arab League member states.

Paragraph 1 stipulated that the travel documents issued for Palestinians by any Arab country should be granted on an equal basis with the national passports issued to its own citizens. Paragraph 2 stated that bearers of such documents "shall be accorded the same treatment as nationals of the state issuing this document, as regards freedom of residence, work and movement." In addition, "special measures needed for the implementation" of the first two paragraphs were to be co-ordinated with the PLO. Lastly,
Paragraph 4 contained a provision that had not been included in the Casablanca Protocol nor in any previous resolution: "If a Palestinian perpetrates a crime in any Arab country, the laws of the country of his residence will be applicable."16

The Arab League Secretariat was keen to monitor the problems experienced by Palestinians in host countries and the extent to which the protocol had been implemented. Because of Palestinian support for Iraqi President Saddam Hussein during the 1990-1991 Gulf War, the treatment of Palestinians in Arab countries worsened. The $46^{\text {th }}$ session of the Conference of Supervisors of Palestinian Affairs in the host countries in August 1991 called Arab countries to abide by their pledges in the treatment of Palestinian refugees in Arab states and reminded with the spirit of Arab brotherhood to overcome the negativity of the Gulf War. ${ }^{17}$

Nevertheless, Palestinians in Egypt were punished as a result of the PLO's position on Iraq. Shiblak considers two factors affecting the treatment of Palestinians in Arab countries. ${ }^{18}$ Firstly, the commitment of Arab states to Arab League resolutions varied and was influenced by politics within these states. Secondly, the treatment of Palestinian refugees in host countries was not governed by clear guidelines or legislation. Stateless Palestinians in Egypt were victimized by such politics. ${ }^{19}$ Despite the fact that Palestinians have a home, they remain stateless until there is a Palestinian state. Palestinians in Egypt who are holders of Egyptian travel documents have had no basic human rights since 1978. They have no access to free education (except for children of PLO officers), have no right to work in the public sector, and their work in the private sector is conditional on regulations set for foreigners. Palestinians have no right to free university education. Their rights to ownership are quite limited, except for those fields which come under the investment law.

\section{Validity of Egyptian Travel Documents}

Since 1960, Egypt has been issuing the "Egyptian Travel Document for Palestinian Refugees," valid for five years. Its validity, however, is contingent on the renewal of one's residence permit. Renewal requirements vary according to the year of arrival. The Department of Passports and Nationality categorizes the residence renewal period as follows, by arrival year: ${ }^{20}$

- before 1948 , renewable every five years, or every ten years with proof of ten-year continuous residence in Egypt;

- 1948 , every five years; ${ }^{21}$

- 1956, every three years;

- 1967, every three years;

- after 1967, every three years, or may vary according to the conditions of entry into Egypt. 


\section{Finding a Residence Permit Guarantor}

Despite Palestinians in Egypt being refugees or displaced persons and unable to go back to Palestine due to its occupation, being granted residence permits is conditional on providing a reason for remaining in Egypt. This could be for education, licensed work, marriage to an Egyptian, or business partnership with an Egyptian. As the following interview shows, an official document, proving that the applicant lives in Egypt for one of these reasons, must be provided.

I sometimes rush around for days to finish paperwork to renew my children's and husband's residence permits. I am in charge of all the paperwork for travel documents and schools. All have three-year residence permits. The children get their residence permits based on the fact that I am Egyptian and my husband gets his based on a letter from a factory claiming that he works there and a letter from the Labour Union. Although he does not work in a factory, the owner was kind enough to give him this letter on a yearly basis. The renewal of the residencies cost us LE 500 for seven persons - my husband and my six children. I sometimes run out of money and borrow from my family to help pay the fees (P22, Faisal, Cairo, June 15, 2002). ${ }^{22}$

Those working with or those who had worked with the Egyptian government, the Office of the Governor of Gaza, or the PLO have the fewest problems renewing residence permits. A letter from their workplace proving employment or retirement facilitates renewal. The majority of Palestinians in Egypt who work in the informal sector without work permits or stable jobs, however, face the greatest obstacles. Many have found their own ways of overcoming this problem.

Getting a work permit as a taxi driver is much easier than getting it as an owner of an electrical repair workshop. That would require providing proof of commercial registration, insurance and licences for the shop. All this requires money and permits that I can't provide. If an inspector comes to the workshop, I would need to give him five to 10 pounds so that he won't report that the workshop is not registered (8/11, Shubra Al-Khaima, Cairo, June 12, 2002).

When performing illegal or unlicensed work, Palestinians often present a taxi driver's licence to the authorities when they renew their residence permits. These licences are not difficult to obtain. Alternately, an agricultural labour licence, which can be obtained with a letter from the labour union, may also be used for proof of being an unskilled labourer.

An agricultural labour permit usually costs one or two pounds. For a permit as a shop owner, I may need to pay 16 pounds a month as insurance. In the past, I was able to get an agricultural labour permit easily but now it is not as easy. The administration at the Mogamma (a government complex that includes all bureaucratic departments) in Cairo may ask to look at my hands and see that I don't have the hands of a farmer (7/37, Faqous, Sharqieh, July 14, 2002).

A major concern of interviewees was the renewal of residence permits for young men. They can be deported at age 18 if they had to drop out of school because of inability to pay private school fees-since, as foreigners, they have no right to free school education, or at age 21 if they graduate from university and cannot find licensed work. Many in such positions are forced to live illegally until they can provide the authorities with an official reason for their stay.

My son became an illegal resident when he turned 21. The officer at the Mogamma - a complex that includes all bureaucratic departments - in Cairo told me that he would soon be deported. My son had never gone to school because he had a fever when he was a baby that affected his brain. His sisters and I get our residencies renewed based their father's pension as a former PLO fighter (P24, Wailey, June 24, 2002).

If no justification for one's stay in the country can be provided, a bank statement showing a balance of at least LE 20,000 may be accepted by the Mogamma.

We had to deposit 20,000 pounds to get a residence permit for my eldest son when he turned 21. Now, we have to deposit another 20,000 for our younger son (AP2, Hilmiat Al-Zaytoun, Cairo, August 5, 2002).

Stateless Palestinians living in Egypt without legal residence or renewed travel documents not only risk illegal stay for themselves but also for their children. For example, Rania's residence permit depends on her Egyptian mother as a guarantor. Despite the fact that her husband works in a business, he has no work or residence permit.

My second daughter is married to a Gazan who runs a business for a Saudi. He has neither a residence permit nor a work permit. He put 20,000 in the bank to get a residence permit but it has not been issued (P22, Faisal - Cairo, June 15, 2002).

For many young Palestinian men and women, early marriage to Egyptian partners is a means of obtaining a guarantor to legalize one's stay in Egypt.

My son will soon turn 21. His father and I are thinking of getting him married soon. We have asked for the hand of my niece, an 
Egyptian, but her parents refused because my son is Palestinian. We have ensured the situation of our two daughters who are both engaged to Egyptians. Eventually they will get Egyptian nationality (8/3, Abu Zaabal- Qaliubieh, June 30, 2002).

While an Egyptian man can naturalize his Palestinian wife and her children since the nationality law stipulates that the wives and children of Egyptian men are automatically granted Egyptians nationality, women married to Palestinian men are not able to do the same. ${ }^{23}$ A committee was formed in September 2003, in a response to President Mubarak's call, to amend the law and enable Egyptian women to naturalize their children; the law however, excluded Egyptian women married to Palestinian men from passing on their nationality to their children. ${ }^{24}$

Moreover, fees for renewing the residency for poor Palestinian families without regular income are a major concern. In case of any delay in renewing the residence permit, they may be threatened with fines.

I was once late in renewing permits for me and my six children because I did not have enough money. They wanted to fine me LE 315. I submitted an appeal and was exempted from the fine. They renewed the residencies as usual (7/30, Belbeis- Qaliubieh, July 2002).

Statelessness is a critical obstacle to the enjoyment of basic rights. Palestinians who have Egyptian travel documents are de facto stateless. The travel document does not designate nationality; it is merely a laissez-passer.

Ahmed: "We have not renewed our residence permits for more than 14 years. Our mother is Jordanian - (Jordanian women cannot pass on their nationality to their children) and our father, who looked after these issues, used to travel with the PLO army. It was only when my father was put in prison that we realised that we should renew our travel documents and had to pay a penalty of 2,000 pounds."

Um Ahmed: "Seeing how difficult it was to renew the travel documents, I went with my daughter to the 'republican palace' and we pleaded with the head of the 'republican guard' to help. He promised to help and said there was no need to meet with the president. He told us to go to the Zaqaziq Passport Section. When I sent my son, they renewed his travel document but refused to renew the documents of his five brothers. If we aren't soon able to obtain a travel document for my daughter, she may lose her fiancé. She needs legal status to register her marriage."

Ahmed: "I am rarely worried about not having a residence permit. When I am stopped, I show them my unrenewed docu- ment. I know they can't read and don't understand the travel document details" (7/25, Abu Hammad, Sharqieh, July 10, 2002).

\section{Difficulties Faced Using an Egyptian Travel Document}

Article 3 of the Arab League's Casablanca Protocol states, "When their interests so require, Palestinians presently residing in the territory of $(\ldots)$ shall have the right to leave the territory of this state and return to it." However, the situation for those leaving the country differs from the protocol statement. Palestinians who leave Egypt can ensure their return in two ways. They must either return every six months or provide papers proving they are working or documents stating educational enrolment abroad. In this case, a one-year return visa may be granted. Any delay in return beyond this date, however, results in denial of entry.

Two of my children have been denied re-entry to Egypt. I have not seen them since they left. One is a lawyer in Libya and the other has a photocopy centre. Neither has as work contract in Libya (7/36, Faqous, Qaliubieh, July 14, 2002).

Due to the limited work opportunities in Egypt, many Palestinians seek work in Gulf countries, Libya, or elsewhere. They may be reluctant to do so, however, because of the possibility that their return to Egypt may be denied.

I used to go to Libya when the borders were open and travel was easy. The problem is that I had to come back to Egypt every six months to keep my Egyptian residence permit. I was unable to apply for a one year return visa because I never had official contracts in Libya and was working in various places. In 1995, I decided to come back after seeing what happened to my brother when he returned from Yemen. He was detained at the airport for several days and then deported back to Yemen despite the fact that he had an Egyptian travel document and regularly renewed his residence (7/37, Faqous, Qaliubieh, July 14, 2002).

Palestinians returning to Egypt from abroad, particularly after the 1990-1991 Gulf War, encountered many problems as a result of the PLO's stance on the Iraqi invasion of Kuwait. Egyptian newspapers published reports on Palestinian students registered at Egyptian universities being prevented from entering Egypt. ${ }^{25}$ There were also reports of Palestinians held in airports and then deported to Sudan.26 Many who had Egyptian travel documents and who lived in Kuwait or elsewhere in the Gulf were denied re-entry to Egypt.

My son, who was studying in Poland, graduated in 1991 and tried to come back to Egypt. In the airport, he was prevented 
from entering. That was a result of the Palestinian position on the Gulf war. He was forced to go to Sudan and then to Yemen, where he is now (P16, Ain Shams, Cairo, June 8, 2002).

After the 1990-1991 Gulf War, Gulf countries also restricted the entry of Palestinians holding Egyptian travel documents. Um Mohamad's family is one example.

My son is working in the Emirates [where he was working before the Gulf War]. He has an Egyptian travel document. Surprisingly, three years ago, when trying to join her husband, his wife and her children [who are also holders of the Egyptian travel documents] were sent back [to Egypt] from Dubai airport, she was refused permission to enter the country despite the valid visa in her passport. She came back and has been living with us for the last three years and her husband comes to Egypt every six months to renew his residence and see her (AP2, Hilmiat Al-Zaytoun, Cairo, August 15, 2002).

Further problems arose for Palestinians when Libyan President Muammar Qadhafi in 1995 ordered all Palestinians residing in Libya to go to Palestine as a means of pressuring Israel to accept all Palestinian refugees returning to their properties after the Palestinian Authority was established. This was intended to put pressure on Israel to repatriate them. As a result, some Palestinians trying to get to Palestine via Egypt were stranded for two years on the Egyptian-Libyan borders at Salloum Camp.

My brother used to live in Libya. He was among those stranded at the border. For nine months he remained in the camp but he managed to get smuggled back into Libya. He worked illegally as a teacher in a private school and his salary was given to him as an allowance [per hour worked] but not as a salary. He then managed to find a way to get smuggled into Egypt. Today, he has a bakery registered in his wife's name and lives illegally in Egypt (7/27, location held for security reasons,July 10, 2002).

Detaining Palestinians at the border is a common occurrence, particularly for those who are stateless and have only the Egyptian travel document. One example is Abu Saqer, born in Cairo in 1976 and carrying an Egyptian travel document, who had been living in Moscow. When his Russian residence permit expired, he decided to go to Egypt to see his family and then reapply to return to Moscow. On arrival at Cairo airport in August 2001, he was denied entry and was returned to Moscow. In turn, the authorities in Moscow prevented him from entering Russia because of his expired residence permit. He was stranded at the Moscow airport for at least fourteen months. ${ }^{27}$ (Al-Hayat, Raed
Jaber, November 9, 2002). Eventually, he was granted asylum in Sweden. ${ }^{28}$

\section{Detention of Stateless Palestinians in Egypt}

As has been described, being stateless and only holding an Egyptian travel document is problematic for many reasons and stateless Palestinians may be detained for indeterminate periods of time.

My son has a category $\mathrm{H}$ travel document. He is able to renew his residence with his Egyptian wife as a guarantor. Last year, he went with his friends to summer camp. His friends were calling my son, 'Pasha, Pasha!' [a title given to a high ranking officer at the military]. An officer who was passing by overheard them and asked my son to show his ID. As he did not have his travel document with him, he was accused of forging the identity of an officer (since he was called by his friends as Pasha) and he was put in prison for 11 months. (7/29, Abu Kbir, Sharqieh, July 2002).

When arrested, Palestinians may be sentenced or deported, regardless of the grounds for arrest. In some cases, state security officials require the family of the person arrested to apply for visas to countries that may accept him or her.

\section{Finding a Way Out}

With the establishment of the Palestinian Authority in the West Bank and Gaza in 1993, many Palestinians applied to Palestinian embassies in various countries to return. ${ }^{29}$ Return to Gaza and the West Bank was seen as a way of escaping the humiliating illegal status many of them endured in exile. At the discretion of Israeli authorities, some were permitted to return. Palestinians granted permission to return from Egypt were given Palestinian identity cards on arrival in Gaza and were issued Palestinian travel documents that are renewable every three years. Palestinian women whose parents still lived in Gaza were able to apply for their children and husbands to join them through the family reunification program. ${ }^{30}$ Other Palestinians were able to go to Gaza by applying for a visiting permit, or tasrieh zyara, through families living in Palestine. The permit is usually valid for three months and is issued by the Israeli authorities, who continue to control the borders of Palestinian Authority areas.

My wife and children in Palestine got Palestinian travel documents. It was easy because my wife has an ID and applied for us under the family reunification programme. My papers for the Palestinian travel document were halted as a result of the Intifada. However, I know many people who left here and are now there [Gaza] with no IDs or any legal papers and have over- 
stayed the time permitted...I wonder how they live there. I personally want to go live and work there. But I do not want to go unless all my papers are processed. I have even applied to the police force in Gaza. I used to be an officer in the PLO Liberation Army...Taking the [Palestinian] ID resulted in losing my threeyear residence permit in Egypt and now I have only a one-year residence (P5, Dar Al-Salam, Cairo, May 18, 2002).

Many of those who returned to Gaza from Egypt had been part of the PLO. When interviewed, many Palestinian families in Dar Al-Salam and Wailey (in Cairo) referred to family members and acquaintances who had left Egypt for Palestine. Some of those who left kept their houses in Cairo. Others moved everything to Gaza. However, not everyone was lucky enough to be allowed to enter Gaza and they expressed their dismay, wondering when their troubles in exile would end.

As far as I know, those who used to work for the PLO were the ones able to apply for a Palestinian ID. I would love to have any passport other than this [Egyptian] travel document. Even when I ask to marry a woman, I am refused because the parents do not want to see their grandchildren suffer as I suffer $(8 / 2$, Ishbin Al-Qanater, Qaliubieh, July 4 2002).

The Palestinian passport (laissez-passer) issued by the Palestinian Authority to Palestinian Arabs living in the West Bank and Gaza is recognized by more than eighty states. ${ }^{31}$ In spite of this, it is not recognized as proof of citizenship and most countries require visas. These can be difficult to obtain because of lack of mobility between Palestinian cities and into Jerusalem. Permits may be obtained from Israel to travel to an embassy or consulate in Jerusalem or Tel Aviv and these permits are not always granted by the Israeli authorities. However, the Palestinian passport has certainly helped many to travel outside Palestine. Palestinians from the West Bank must have both the Palestinian document and a valid Jordanian passport. It is also problematic for Palestinians who went back to Egypt because it rendered them de facto and de jure foreigners.

I hold the Palestinian travel document since I was given a Palestinian ID. I thought it would be better to have a Palestinian travel document. It turned out to be more difficult. Life in Egypt became more expensive for us. With the Egyptian travel document, we had some privileges, especially since I am a former Ain Jalout officer. My children were able to go to public schools. But now we are considered foreigners (P11 Ain Shams, Cairo, May $28,2002)$.
Regardless of the duration of their stay in Egypt and whether or not they once held an Egyptian travel document, Palestinians with Palestinian travel documents are required by Egypt to apply for residence permits as foreigners. The "privileges" they used to have in Egypt have been lost.

My father, who now works with the PA, issued us all Palestinian IDs, but we kept our Egyptian travel documents. Since we came back from Palestine, the governor of Gaza has not agreed to renew our residence permits using the Egyptian travel document. They require us to get a Palestinian travel document on which basis the residence will be given since we now have Palestinian IDs (7/46, Menya Al-Qameh, Qaliubieh, July 11, 2002).

\section{Further Difficulties for Stateless Palestinians}

Many who spoke to us said that young Palestinians who had problems renewing their residence permits at age 21 and who had problems in finding employment were more likely to try to leave for Gaza. Many young Palestinian men in Egypt have applied to join the Palestinian Authority (PA) in Gaza in the hopes of earning a regular income and regularizing their legal status. Those who were not able to join the PA still tried to move to Gaza. Some applied for a visitor's permit through family in Gaza or the West Bank. Once they arrived in Gaza, some Palestinians would overstay their permits. Leaving Gaza would then be difficult because they could be penalized or jailed by the Israeli authorities. In many cases, returning to Egypt became impossible since their residence permits for Egypt would have expired after six months. During interviews, many of the Palestinian women who married in Gaza told us that they had subsequently lost their legal status in Egypt. Today, many live illegally in Gaza as stateless persons. The outbreak of the Intifada in 2000 further delayed the processing of applications for IDs for the family reunification program.

I know many people who left here and now live there [Gaza] with no IDs or legal papers and who have exceeded their stay... I wonder how are they living there (P5, Dar Al-Salam, Cairo, May 18, 2002).

For many, living illegally in Palestine has been the only solution. For some, it offers hope of being at "home with the family."

My son was living in Libya when the authorities confiscated his house and asked him and his family to leave in 1997. Through his cousins, he was able to get a permit to visit Gaza. He went to live there illegally with no papers. He obviously lost his residence permit in Egypt when he was in Libya and was then 
deported from Libya. He was given a visit permit for Gaza and this has also expired.... At least he is living with his family in the homeland "Palestine" (AP3, Alexandria, August 2002).

\section{Assistance and Protection under International Refugee Law}

Relief and assistance are urgent needs for refugees who have left their properties and homes in search of asylum. However, protection of the refugee's basic human rights is of the utmost importance. The degree to which these rights are respected varies depending on the politics of the state and the conventions and protocols ratified by the host country. While agreeing to shelter Palestinian refugees on a temporary basis, Arab countries have been keen to place responsibility for the Palestinian refugee problem on the "international community"; calling for UN Resolution 194 (1948) became the means to remind the world of its responsibilities vis-à-vis the refugees. Arab countries have reminded the international community of the moral necessity of keeping the issue on the agenda and have reiterated the need for implementing international resolutions concerning this group of refugees. Considering that the United Nations adopted Resolution 181 in 1947, which created the State of Israel and displaced Palestinian refugees from their homeland, Arab countries have called for the implementation of other UN and international conventions to protect the rights of Palestinian refugees and to ensure their return to their properties in Palestine.

\section{United Nations Resolutions on Protection}

As the situation worsened after the adoption of GA Resolution 181 and more than half a million Palestinians were forced to leave their homes, the General Assembly established the United Nations Mediator for Palestine, which in June 1948 established a UN Disaster Relief Project (UNDRP) in an attempt to coordinate aid efforts amongst local governments and relief organizations and to mediate and promote a truce. UNDRP had a sixty-day mandate to coordinate aid to the refugees from governments and nongovernmental organizations. It was succeeded in November 1948 by the UN Relief for Palestine Refugees (UNRPR), which later became UNRWA. ${ }^{32}$

According to the terms of reference of GA Resolution 186 of May 14, 1948, the Mediator was given the task of promoting a peaceful adjustment of the future situation in Palestine. Additional tasks included arranging for the operation of common services necessary for the safety and well being of the population in Palestine, protection of the Holy places, directives to co-operate with Truce Commission for Palestine, and to invite assis- tance and cooperation of additional agencies for the promotion of the welfare of the inhabitants of Palestine. ${ }^{33}$

The mediator also dealt with Palestinian refugees and suggested to Israel that it allow a number of refugees to return to their homes. In his September 1948 report, Count Folke Bernadotte, the United Nations emissary to Palestine, called for the return of Palestinians as a "right": "From the start, I held the firm view that, taking into consideration all circumstances, the right of these refugees to return to their homes at the earliest practical date should be established." Bernadotte recommended that the General Assembly establish a conciliation commission to supervise a final settlement of the claims of Palestinian refugees. His mediation efforts ended with his assassination by Jewish terrorists on September 17, 1948, only one day after he submitted his last progress report.

\section{United Nations Conciliation Commission for Palestine (UNCCP)}

In view of the mediator's recommendations, on December 11, 1948, the General Assembly established the United Nations Conciliation Commission for Palestine (UNCCP) to "assist the Governments and authorities concerned to achieve a final settlement of all question outstanding between them." The Commission was formed with the adoption of Resolution 194 (III) and replaced the late mediator's mandate in resolving all aspects of the conflict by taking on his previous functions of facilitating a peaceful settlement. The Commission was also responsible for the direct protection of refugees' rights and interests and for implementing the durable solution of repatriation, resettlement, and rehabilitation while at the same time ensuring a peaceful settlement. Paragraph 2 of the resolution included the following:

Resolves that the refugees wishing to return to their homes and live at peace with their neighbours should be permitted to do so at the earliest practicable date, and that compensation should be paid for the property of those choosing not to return and for loss of or damage to property which, under principles of international law or in equity, should be made good by the Governments or authorities responsible;

Instructs the Conciliation Commission to facilitate the repatriation, resettlement and economic and social rehabilitation of the refugees and the payment of compensation and to maintain close relations with the Director of the United Nations Relief for Palestine Refugees and, through him, with the appropriate organs and agencies of the United Nations. 
Terry Rempel argues that the UNCCP was assigned with a dual mandate: a broad mandate for conciliation of all outstanding issues between the parties, and a specific mandate for the protection and promotion of a durable solution for Palestinian refugees. ${ }^{34}$ This dual mandate created a conflict of interest for the commissioner, making it difficult if not impossible to protect and promote the specific rights of refugees. Due to Israel's opposition to repatriation, the protection of refugees' right to return home became difficult. Attempts at peace demanded a compromise the conflicting parties were not ready to make. This placed an insurmountable obstacle in the way of the Commission's mandate and hampered any progress to achieve a framework for a durable solution for Palestinian refugees.

The UNCCP was hard-pressed to provide protection and facilitate implementation of the durable solution for Palestinian refugees. It established two bodies - the technical committee and an Economic Survey Mission (ESM) - to investigate ways of determining refugee choices and improving their immediate situation. By June 1949, the UNCCP charged the technical committee with the task of gathering the necessary data for the implementation of durable solutions set down in Resolution 194 (III) related to repatriation and payment of compensation. In its report, the technical committee based its recommendations on the assumption of resettling large numbers of refugees outside Israel. The committee also dismissed the idea of determining individual refugee choices as "premature," stressing that repatriation, unlike resettlement, was a "political decision." 35

Later, in November 1949, the ESM, which was established to "facilitate the repatriation, resettlement and economic and social rehabilitation of the refugees," made a recommendation:

[t]o reintegrate the refugees into the economic life of the area on a self-sustaining basis within a minimum period of time; and to promote economic conditions conducive to the maintenance of peace and stability in the area.

The ESM's recommendations focused on resettlement and advocated finding job opportunities for refugees in host countries.

They [Palestinians] believe, as a matter of right and justice, they should be permitted to return to their homes, their farms, ...They are encouraged to believe this remedy open to them because the General Assembly of the United Nations said so in its resolution of 11 December 1948...
But repatriation of Arab refugees requires political decisions outside the competence of the Economic Survey Mission.

Why do not the refugees go somewhere else? Why not resettle them in less congested lands?...In these circumstances, the only immediate constructive step in sight is to give the refugees an opportunity to work where they now are. ${ }^{36}$

The UNCCP failed to achieve its goals. Israel considered the establishment of an Arab-Israeli agreement to be a prerequisite for repatriation. The Arabs, in turn, considered the right of return as essential for making peace with Israel. Neither Israel nor the Arab countries neighbouring Israel wanted to compromise, and the hopes for resolving the refugee problem diminished.

Under U.S. pressure, Israel finally agreed to repatriate 100,000 refugees but expected Syria and Jordan to settle the rest. The Commission did not agree to these conditions and refused to present the offer to the Arabs, who in principle were opposed to dividing repatriation. However, the UNCCP did attempt to facilitate the repatriation of refugees who wanted to return to Israeli-controlled areas. It approached the government of Israel to secure the return of the former inhabitants of the no-man's land in the north Gaza region, refugees in Egyptian-administered Gaza, and refugees in the Gaza zone originating from the Beersheba area. Only small groups were returned, however. Refugees from Abasan and Akhzah were permitted to return to cultivate land. Others were permitted to return if the family breadwinner had remained in Israel. In December 1948, a total of 800 dependents from Lebanon and Jordan rejoined their families in Israel and 115 came back from Gaza. ${ }^{37}$

In addition to securing the return of these refugees, though few in number, the UNCCP was also successful in the protection of refugee properties. The commission called for the annulment of Israel's 1950 absentees' property law, under which refugee property had been expropriated. The UNCCP also called for the suspension of all measures of requisition and occupation of Arab houses and for the unfreezing of Waqf (religious endowment) property. ${ }^{38}$ In 1950, it established a Refugee Office to determine the ownership, interest, and nature of each refugee property. The office also prepared an initial plan for the individual assessment of refugee properties relying on detailed information collected from refugees. By 1964, the office had collected 453,000 records amounting to 1,500,000 individual refugee holdings. ${ }^{39}$ The UNCCP maintains the most comprehensive records of Palestinian refugee properties. However, within four years of its formation, the UNCCP devolved from an agency charged with the "protection of the rights, 
property and interests of the refugees" to little more than a symbol of UN concern for the unresolved Arab-Israeli conflict. $^{40}$

\section{Article 1D 1951 Refugee Convention: Applicability to Palestinian Refugees}

The Travaux Préparatoires of the 1951 Geneva Convention relating to the Status of Refugees state, "the shared intention of the Arab and Western states was to deny Palestinians access to the Convention-based regime so long as the United Nations continues to assist them in their own region." ${ }^{41}$ UNRWA was created to provide assistance for the refugees based on UN Resolution 302 (IV) of 1949, while UNCCP had been expected to provide for their protection based on UN resolution 194 (III). Hence, Palestinian refugees who are assisted by UNRWA are not included in the 1951 Convention relating to the Status of Refugees. The Convention establishes specific rights of refugees and prescribes certain standards for their treatment. As a minimum standard, the Convention states that refugees in the country of asylum should receive at least that treatment which is accorded to aliens in that country. ${ }^{42}$ Once recognized by the UNHCR, the refugee should be treated on a par with nationals in the country of refuge and should be granted basic rights, including rights to education, association, wage-earning employment, and access to the courts.

The 1951 Convention defines a refugee as a person who:

... owing to a well-founded fear of being persecuted for reasons of race, religion, nationality, membership of a particular social group or political opinion, is outside the country of his nationality and is unable or, owing to such fear, is unwilling to avail himself to the protection of that country; or who, not having a nationality and being outside the country of former habitual residence as a result of such events, is unable or, owing to such fear, is unwilling to return to it.

The Convention contains provisions whereby certain persons, otherwise having the characteristics of refugees as defined in Article 1A, are excluded from UNHCR's mandate. One such provision, as stated in Paragraph 1 of Article $1 \mathrm{D}$, applies to a special category of refugees for whom separate arrangements have been made to afford protection or assistance.

This Convention shall not apply to persons who are at present receiving from organs or agencies of the United Nations (UN) other than the UNHCR protection or assistance. When such protection or assistance has ceased for any reason, without the position of such persons being definitively settled in accordance with the relevant resolutions adopted by the General Assembly of the UN, these persons shall ipso facto be entitled to the benefits of this Convention.

In a note on the applicability of Article 1D of the 1951 Convention on Palestinian Refugees, the UNHCR (2002) said:

Paragraph 1 is in effect an exclusion clause, and this does not mean that certain groups of Palestinian refugees can never benefit from the protection of the 1951 Convention. Paragraph 2 of the Article 1D contains an inclusion clause ensuring the automatic entitlement of such refugees to the protection of the 1951 Convention if, without their position being definitively settled in accordance with the relevant UN General Assembly resolutions, protection or assistance from UNRWA has ceased for any reason. The 1951 Convention hence avoids overlapping competencies between UNRWA and UNHCR, but also, in conjunction with UNHCR's Statute, ensures the continuity of protection and assistance of Palestinian refugees as necessary. ${ }^{43}$

Palestinians living in Egypt, who do not receive the relief and assistance provided by UNRWA, fall, therefore, within Paragraph 2 of Article 1D and should automatically be entitled to the benefits of the 1951 Convention and fall within the mandate of the UNHCR, "providing of course that Article 1C, 1E and 1F do not apply." "44 However, the Convention has not been consistently applied to Palestinians outside UNRWA's mandate. Susan Akram analyzes the article's "protection or assistance" and "ipso facto" phrases, which intended to provide Palestinian refugees with continuity of protection under various organizations and instruments. ${ }^{45}$ In a regime of heightened protection, Akram argues, two agencies have been set up for Palestinian refugees: UNRWA, which was to be the assistance agency, and the UNCCP, which was to be the protection agency. ${ }^{46}$ Article 1D's function was to ensure that if for some reason either of these agencies failed to exercize its role before a final resolution of the refugee situation, that agency's function was to be transferred to the UNHCR and the Refugee Convention would fully and immediately apply without preconditions to the Palestinian refugees.

According to Takkenberg, Egypt ratified the Convention in 1981 but was

reluctant to become bound by the 1951 Convention, apparently out of a perceived conflict between the status favoured by the Arab League and that of the Convention, and also because for many years the PLO had opposed providing individual Palestinian refugees with the status of the 1951 Convention because this was considered prejudicial to the inalienable rights of the Palestinian people. 
Hence, despite the fact that since 1981 Palestinians in Egypt fall under the mandate of the 1951 Convention, they have been treated according to the Arab League's special status designations. In Egyptian administrative offices, for example, separate sections are responsible for different groups of refugees; one is for Palestinians refugees and another is for 1951 Convention refugees. ${ }^{47}$

Arab countries were instrumental in bringing about the unique role of the United Nations in relation to Palestinian refugees. The UN recognizd that it was partially responsible for creating the refugee situation through General Assembly Resolution 181 which recommended the partition of Palestine. ${ }^{48}$ However, Arab states advocated Palestinian exclusion from the 1951 Convention and from UNHCR's mandate primarily because they were concerned that, if included under the UNHCR mandate, Palestinian refugees "would become submerged [within other categories of refugees] and would be relegated to a position of minor importance. ${ }^{49}$ This concern was based on political rather than legal considerations. In many Arab League meetings, governments voiced fears that the Palestinian plight would not be adequately addressed if UNHCR's durable solutions such as resettlement to a third country or settlement in the first country of asylum were applied. ${ }^{50}$ The Palestinian refugee problem, they argued, was to be resolved on the basis of a special formula of repatriation and compensation rather than the formula commonly accepted for refugees at the time, which was resettlement in a third country. ${ }^{51}$

Given that the UNCCP's ability to offer protection to Palestinians was weakened by its dual mandate, and because the 1951 Convention continues in large part not to be applied to Palestinians, Palestinians have been left with no agency to protect their legal rights. This has had particularly dire consequences for stateless Palestinians who have been denied rights in host countries. Due to the fact that Palestinians who fled to Arab countries were not granted citizenship and lost their citizenship in Palestine, many Palestinians are now stateless. ${ }^{52}$

\section{Statelessness}

Two international conventions are relevant to Palestinians who are stateless refugees and to whom the 1951 Convention has not been applied - the 1954 Convention relating to the Status of Stateless Persons and the 1961 Convention on the Reduction of Statelessness. To benefit from these two conventions, "a person must be determined to be stateless, that is a person who is not considered a national by any state under the operation of its law." ${ }^{53}$

The determination of statelessness involves a mixture of legal definitions and factual circumstance. A stateless person is defined as a person who is not recognized as a citizen by the laws of any state, i.e., de jure stateless. This category includes Palestinians who hold travel documents, such as Egyptian, Lebanese, and Syrian travel documents, temporary Jordanian passports (Gazans and West Bankers) and those who hold Palestinian passports which are only travel documents, or laissez-passer.

In addition to the legal implications, statelessness results from a particular set of historical events and may be perpetuated by inability to acquire a new nationality, i.e., de facto stateless. As a product of the British Mandate's authority, Palestinian citizenship ended along with the mandate and with the proclamation of the State of Israel. Thus, those Palestinians who lost their citizenship then and did not or could not acquire new citizenship fall into this category. Also included within this group of de facto stateless persons are those who were born in a country of residence and denied citizenship and the rights it entails. For instance, this group includes the children of a mother who holds the nationality of the host country and whose husband is a stateless Palestinian. Even if the children were born or lived most of their lives in their mother's country, they are deprived of citizenship. A large number of those persons are said to be found in Egypt. Hala Abdel-Qader estimates the number of Egyptian women married to foreigners to be $286,000 .^{54}$ According to her unofficial estimates, the number of stateless children born to these women exceeds one million. Despite the fact that Egypt has signed the United Nations Convention on the Elimination of All Forms of Discrimination against Women (CEDAW), the government has refused to ratify the second section of Article 9 of CEDAW, which stipulates that: "States Parties shall grant women equal rights with men with respect to the nationality of their children." 55

The two conventions on statelessness relate to Palestinians who are refugees and are stateless but to whom the 1951 Refugee Convention does not apply. The 1954 Stateless Convention has a clause similar to the 1951 Convention stipulating it "shall not apply to persons who are at present receiving help from organs or agencies of the United $\mathrm{Na}$ tions other than the United High commissioner for Refugees protection or assistance so long as they are receiving such protection or assistance. ${ }^{36}$

The limited applicability of this article to Palestinian refugees and the previously mentioned conventions has excluded Palestinians from enjoying all of their basic human rights. It is noteworthy that the basic definition of "stateless persons" is now considered part of international customary law and is therefore binding even on states that are not party to one or other of these conventions. ${ }^{57}$ Notwithstanding the articles of the Universal Declaration of Human Rights, which recognises the inherent dignity and 
the equal and inalienable rights of all members of the human family as the foundation of freedom, justice and peace in the world, Palestinians have been labelled as not having the "the right to have rights" ${ }^{58}$ In principle, Palestinian resident non-nationals should acquire vested rights and should be treated on a par with nationals in host countries.

\section{National Protection}

Two main principles have influenced the attitudes of Arab League member states to vis-à-vis Palestinian refugees. The first is their support for the Palestinian cause, on which basis they agreed in the Casablanca Protocol, which Egypt ratified in 1965, to grant Palestinian refugees residence and the right to work and travel on the same footing as citizens. The second principle refers to their vow to preserve Palestinian identity and maintain the refugee status of Palestinians in order to hold Israel responsible for the creation of the Palestinian refugee plight. Hence, Palestinians were to be granted basic rights but not naturalised. One exception is Jordan where Palestinians were granted citizenship. Small numbers of Palestinians in Lebanon and Egypt were also granted citizenship. However, no clear pattern was found to justify the grounds under which the citizenship was granted.

In Egypt, as of the end of 1970s, Palestinians were treated as foreigners and were deprived of the basic rights and equal treatment they had been promised. While Egypt's political stance on the Palestinian issue is seen as important and supportive, in practice no basic rights have been provided for Palestinians as a result of political events and strained relations between the Egyptian government and the PLO. This, in turn, has affected the livelihood of Palestinians in Egypt.

\section{Ambiguous Legal Status Needs Rectification}

Since 1952, the UNCCP has failed to provide Palestinian refugees with basic international protection. Owing firstly to the inability of the UNCCP to reconcile the internal contradictions involved in its mandate and due to its inability to take "political decisions", refugee protection has been limited to those issues about which there was the least amount of disagreement, namely the documentation and evaluation of refugee properties for payment of compensation.

Although very few Palestinians have been assisted by UNHCR to date, those who live outside UNRWA's area of operations are included in the 1951 Refugee Convention and should be recognised under the revised interpretation of the exclusion and inclusion clauses in Article 1D of the Convention. In addition, Egypt needs to commit itself to fully respecting the basic human rights of Palestinian refugees in light of the Casablanca Protocol and its commitment to alleviating the plight of Palestinians, particularly the
Palestinian refugees and displaced persons residing in its territories.

The ambiguous legal status of Palestinians has affected their livelihoods in many ways. It has rendered their residence insecure and in many cases illegal. This has affected employment and education opportunities, as well as freedom of movement and association. As a signatory to the Universal Declaration of Human Rights and several other covenants on civil and political rights, Egypt should provide basic rights to Palestinians regardless of political circumstances. The deprivation of rights and the unstable legal and economic conditions of Palestinians in Egypt rendered them "in limbo".

\section{Notes}

1. "Host countries" are defined as those areas in which UNRWA operates: Jordan, Syria, Lebanon, the West Bank, and Gaza. Although Egypt received Palestinians, it does not define itself as a host country as such due to the fact UNRWA did not operate within it.

2. Maha Dajani, The Institutionalization of Palestinian Identity in Egypt, Cairo Papers in Social Science, vol. 9, monograph 3 (Cairo: AUC Press, 1986), 41.

3. In 1993, new eligibility rules were issued that widened the categories of Palestinians that could be served by the UN agency. According to the initial definition, only those in need of assistance could apply to UNRWA. The reformulation of the rules in 1993 eliminated the condition of need in order to allow groups of non-registered Palestinians who left Palestine in 1948 to apply. This acknowledged the fact that applying for Palestinian refugee status with UNRWA had certain political implications for the peace negotiations and right of return. This wider interpretation, however, does not include Palestinian refugees in Egypt or in other Arab counties. Yet, this may in the future be used in the permanent status negotiations. See Lex Takkenberg, The Status of Palestinian Refugees in International Law (Oxford: Clarendon Press, 1998).

4. Nadera Sarraj, et al., Arab Palestinians in Egypt (Cairo: Dar Al-Mustakbal, 1986).

5. "Population displacement" is defined as the process of collective dislocation and/or settlement of people away from their normal habitat by a more powerful force.

6. UNRWA expanded its assistance to "other persons in the area who are at present displaced and are in serious need of immediate assistance as a result of the recent hostilities" (UNGA Resolution 2252 (ES-V), July 4, 1967, in Takkenberg, 82). Hence, although UNRWA expanded its assistance to those displaced by the 1967 War, it never expanded its working definition of a Palestine refugee.

7. For more details, see <http://www.mfa.gov.eg/getdoc. asp?id $=131>$.

8. This was possible upon request of an entry permit to Egypt; some restrictions were imposed on mobility between Gaza and Egypt. 
9. Abdul Qader Yassin, "Palestinians in Egypt," Samed El Iqtisadi [journal; published in Amman, Jordan] 18, no. 106 (1996).

10. UNHCR, "Note on the Applicability of Article 1D of the 1951 Convention relating to the Status of Refugees to Palestinian Refugees," International Journal of Refugee Law 14, no. 2-3 (2002): 450-56.

11. See below at page 26 for the text of both Article $1 \mathrm{~A}$ and $1 \mathrm{D}$ of the Convention Relating to the Status of Refugees.

12. As noted earlier, in July 1948, the political committee of the Arab League called for the formation of a civil administrative government responsible to the Arab League. In September 1949, the Government of All Palestine was declared as the official government representing Palestinian; see Sarraj et al.

13. Laurie Brand, Palestinians in the Arab World (New York: Columbia University Press, 1988), 51.

14. News clipping, Al-Ahram, April 20, 1960.

15. The Arab states that ratified the protocol without reservation are: Jordan, Algeria, Sudan, Iraq, Syria, Egypt, and North Yemen. Kuwait and Lebanon ratified the protocol with reservations. Morocco and Saudi Arabia did not ratify the protocol. Other Arab states were not yet independent.

16. Takkenberg, 147.

17. The Paragraph 7, Resolution 5093, September 12, 1991, reads as follows:

Having taken notice of the memorandum presented by the delegation of Palestine, the Conference expresses the hope that all Arab states, in a spirit of brotherhood and solidarity, will seek to abide by the Protocol relating to the Treatment of Palestinians [Casablanca Protocol] in accordance with the rules and laws in force in each state, and calls upon the Arab states to overcome the negative impact of the Gulf crisis, as regards the implementation of this Protocol in respect of the Palestinian people. [Citation taken from Takkenberg, 149.]

18. Abbas Shiblak, "Residency Status and Civil Rights of Palestinian Refugees in Arab Countries," Journal of Palestine Studies 25, no. 3 (1996): 36-45.

19. A stateless person is someone not considered a national by any state under the operation of its law, as defined by Article 1 of the 1954 Convention relating to the Status of Stateless Persons.

20. A, B, and C permits and travel documents are processed at the Mogamma, a government complex that includes all bureaucratic departments, in Cairo. Category D and $\mathrm{H}$ papers are processed by the Governor of Gaza in Madinet Naser.

21. After the age of 50, one's residence permit can be renewed free every five years (P17, Ain Shams, June 8, 2002).

22. After each interview quoted in this paper, the number of the interview appears in parentheses (in figures or in letters according to files of the researcher), together with the district, the governorate in Egypt, and the date of the interview.

23. Only recently, a few Arab countries started considering changing the law and permitting women to pass on their nationalities to their spouses and children. By the end of 2003, both Jordan and Egypt, supported by their first ladies, amended the laws but very little has been observed at the practical level.
24. <http://weekly.ahram.org.eg/print/2003/663/eg4.htm>.

25. Al-Sha'b, October 9, 1990.

26. Al-Ahali, Tharwat Shalabi, September 11, 1991.

27. Al-Hayat, Raed Jaber, November 9, 2002.

28. UNHCR Representative, Egypt, personal communication, May 29, 2003.

29. According to some, through negotiations it may be possible to reach an agreement on a quota of 40,000 refugee immigrants to Israel over a period of five years. In any event, it was agreed that Israel has the sovereign right to decide who will enter the territory and who will be barred from entering. See: $<$ http://www.arts.mcgill.ca/MEPP/PRRN/prmepp.html $>$.

30. Israeli conditions for the right of residence are that the person: (1) that the person was registered in the Israeli census in the newly Occupied Territories in 1967, (2) holds an Israeli identity card, and (3) has been visiting the territories regularly, at least every six years, since the census was conducted; see Hovdenak et al., Constructing Order: Palestinian Adaptations to Refugee Life (Oslo: Fafo, 1997), 67. The family reunification program was carried out through those who had Israeli identity cards which later became Palestinian IDs (and were approved by the Israeli authorities).

31. Abbas Shiblak, "The League of Arab States and Palestinian Refugees' Residency Rights,” Shaml Monograph Sereies (Ramalla: 1998).

32. UNRWA, UNRWA Past, Present and Future: A Briefing Document (Vienna: United Nations Relief and Works Agency for Palestine Refugees in the Near East, 1986).

33. Terry Rempel, "The United Nations Conciliation Commission for Palestine, Protection, and a Durable Solution for Palestinian Refugees," Information and Discussion Brief, issue no. 5 (Bethlehem: Badil, 2000).

34. Ibid.

35. Ibid.

36. Takkenberg, 25-26.

37. Rempel.

38. Ibid.

39. The office estimated that a total of 17,167 square kilometres out of 26,320 square kilometres (the total area of pre-1948 Palestine) were determined to be refugee lands; see Salman Abu Sitta, "The Right of Return: Sacred, Legal and Possible," in Palestinian Refugees: The Right of Return, ed. Naseer Aruri (Pluto Press, 2001), 195-207.

40. Susan Akram, "Temporary Protection and Its Applicability to the Palestinian Refugee Case," Information and Discussion Brief, issue no. 4 ( Bethlehem: Badil, 2000).

41. James Hathaway, The Law of Refugee Status (Toronto and Vancouver: Butterworths, 1991), cited in Takkenberg, 90.

42. Ibid.

43. A similar provision to Article $1 \mathrm{D}$ of the 1951 Convention is continued in UNHCR's Statute, paragraph 7(c) of which stipulated that the competence of the High Commissioner shall not extend to a person who "continues to receive from other organs or agencies of the United Nations protection or assistance." 
44. The fact that such a person falls within paragraph 2 of Article $1 \mathrm{D}$ does not necessarily mean that he or she cannot be returned to UNRWA's area of operations, in which case, once returned, the person would fall within paragraph 1 of Article 1D and thereby cease to benefit from the 1951 Convention (Note on Applicability 2002).

45. Susan Akram, "Reinterpreting Palestinian Refugee Rights under International Law and a Framework for Durable Solutions," in Palestinian Refugees: The Right of Return, ed. Naseer Aruri (London: Pluto Press, 2001), 165-94.

46. Ibid.

47. Takkenberg, 125.

48. Akram, 2001, 173.

49. Takkenberg, 66.

50. The review of the preparatory work has also revealed that the international community did not decide to exclude Palestinian refugees from the general legal regime for the protection of refugees. Although the Arab states did not consider themselves primarily responsible for financing the relief effort, they were concerned that assistance or protection be extended to the Palestinian refugees irrespective of whether relief by the United Nations would continue to be provided. They, therefore, made it clear that the provision, included upon their request in the draft convention, was only to exclude Palestinian refugees temporarily See Takkenberg, 66.

51. Akram, 2001, 173.

52. Until a Palestinian state is established and Palestinian passports of that state can be issued for Palestinians in the diaspora, they will remain stateless.

53. Article 1 of the 1954 UN Convention relating to the Status of Stateless Persons.

54. Hala Abdel-Qader, "Statelessness in Egypt," paper presented at the regional workshop Statelessness in Arab World, Ayia Napa, Cyprus (Ramalla: Shaml, 2001).

55. In the first week of May 2001, independent MP and civil society activist, Fayza Al Tahnawi, presented a draft law to the People's Assembly calling for the modification of Article 2 of the Nationality Law (26/1975), which stipulates that only Egyptian men can pass on their nationality to their children. According to the same article, women have the same right only if the father is unknown or stateless. See: Hossam Bahgat, "Living on the Margins: A Parliamentary Proposal Brings the LongIgnored Issue of Citizenship to the Fore," Cairo Times, 10-16 May, 2002.

56. "Unfortunately, adherence to the 1954 Convention is far more limited than in respect of the 1951 Convention," according to Takkenberg. As at September 29, 1994, based on information provided by the Centre for Documentation on Refugees, only three member states of the Arab League are party to the Convention: Algeria, Libya, and Tunisia. See Takkenberg, 186.

57. Akram, 2000

58. Takkenberg, 195.
Oroub El-Abed is an independent researcher working on Palestinian refugee issues and development related themes. She has an M.Sc. in Development Studies from the School of Oriental and African Studies of the University of London. She has conducted several research projects on Palestinian refugees in Egypt and in Jordan. She has a forthcoming book on her complete research on Palestinians in Egypt. She has worked with the Forced Migration Studies Programme at the American University in Cairo, the Shaml Centre in Ramalla, the French research centre IFPO, and the Department of Palestinian Affairs of the Jordanian government. Oroub El-Abed is currently based in Amman, Jordan, and doing consultancies on several development issues related to Palestinian refugees and Iraqis. This paper is adapted from the manuscript for a book "Unprotected in Egypt, Living and Coping as a Palestinian," 2004. 